Article

\title{
Redistribution and Recognition in Spanish Transgender Laws
}

\author{
R. Lucas Platero
}

Social Psychology Department, Universitat Autònoma de Barcelona, Bellaterra 08193, Spain; E-Mail: lucas.platero@uab.cat

Submitted: 31 January 2020 | Accepted: 14 July 2020 | Published: 18 September 2020

\begin{abstract}
Since 2012, 16 laws granting rights to trans individuals have been passed in Spanish regions. How can we assess the quality of these laws? Do they all profoundly and positively transform trans people's well-being? Do they tackle the economic marginalization of trans people? Do they have a symbolic impact? Using multidimensional criteria, I analyze transspecific and LGBTI+ antidiscrimination policies to define trans-positivity in policymaking. This article uses feminist theory to judge this legislation's value, contrasting that with the insights of activists and policymakers interviewed for this purpose. Benefiting from the discussion between Nancy Fraser (1995) and Judith Butler (1997), the quality of trans legislation can be assessed by looking at both cultural recognition and economic redistribution. In addition, following Andrea Krizsan and Emanuela Lombardo (2013), I also analyze these laws through the lens of empowerment and transformation. Having made the elusive relationship between sexuality and political economy in trans laws in Spain visible, I call for greater imagination to envisage other sorts of political actions for trans people.
\end{abstract}

\section{Keywords}

policymaking; recognition; redistribution; Spain; transgender

\section{Issue}

This article is part of the issue "Trans* Politics: Current Challenges and Contestations" edited by Mieke Verloo (Radboud University, The Netherlands) and Anna van der Vleuten (Radboud University, The Netherlands).

(C) 2020 by the author; licensee Cogitatio (Lisbon, Portugal). This article is licensed under a Creative Commons Attribution 4.0 International License (CC BY).

\section{Introduction}

During the last decade, the discrimination transgender people have historically experienced in Spain has been acknowledged (Missé, 2018). Once considered sinful, criminal, and sick, they are becoming intelligible political subjects as their rights are starting to be recognized (Platero, 2011). In addition to the 2007 national legislation that allows trans people to change the name and sex on their IDs, eleven Spanish regions have passed trans-specific legislation along with anti-discrimination policies. These policies are the result of the recognition of a new political subject, the transgender individual. The trans movement, along with other social movements, has now entered mainstream policy-making and other agenda-setting processes. Transgender individuals are given more rights, granting them access to a legal, physical, and social transition, and improving their participation in different social realms.

Yet that successful decade-long narrative of sexualrights achievement in Spain has to be contrasted with the current reality of trans rights, which means looking at both the implementation of specific laws, as well as the ups and downs of shifting political powers. The results of the 2019 national and regional elections revealed new threats, with less bipartisanism and more heterogeneous coalition strategies, in addition to the emergence of a new right-wing party in many regional and local governments. At the time of this writing, the Socialist Party and Podemos are in office in the national government, and the far-right party VOX is in coalition governments in Andalusia, Murcia, and Madrid. With the support of the Conservative Party and Ciudadanos, VOX is visibly working towards dismantling the newly achieved rights for women, migrants, LGBTI+ people, children, people with disabilities, and refugees, among others.

Additionally, the discussion on a new Spanish national law has encountered a fairly new brand of resistance (Platero \& Ortega, 2016) that has only become more conspicuous since 2019, as some feminist leaders in the Socialist Party, as well as some academics, are leading a visible campaign against trans rights, presenting the 
idea of national legislation for trans people as a backlash on women's rights (Álvarez, 2020). In 2020, political debates have been put on hold as Spain struggles with an unprecedented health crisis due to the COVID-19 pandemic. The coalition government has established an emergency-response plan that restricts some freedoms and increases police surveillance, a plan that especially impacts trans individuals who find themselves at the crossroads of multiple inequalities. This new political scenario and the coming recession will have consequences for trans people, which involves a careful discussion on how policymaking is never neutral.

In this complex context, analyzing current trans regional policies can be relevant to envision a future national legislation led by the Socialist and Podemos Government, which was announced through their mandate.

In this article, I assess the quality of Spanish regional policies that regulate transgender rights using Nancy Fraser's (1995) distinction of recognition and redistribution politics, but also Judith Butler's (1997) insight on the bivalent social justice for despised sexualities. My goal is to contribute to the discussion about the still elusive relationship between sexuality and political economy (Merck, 2004). Furthermore, this regional transgender policy analysis explores how choosing certain approaches in policymaking affects the possibilities of trans people having a livable life (being able to have economic independence and agency over their lives, among others).

The article starts with Fraser and Butler's discussion about recognition and redistribution, which I then apply to transgender politics. The next section details my qualitative methodology, which involves an analysis of 16 policy texts and interviews with twenty-one relevant stakeholders. The part after that analyzes the types of laws, their contents, and their construction under the categories of recognition/distribution. The penultimate section assesses the quality of transgender laws in Spain. My conclusions then highlight the emphasis on recognition politics for trans people, and the relevance of imagination and play when we imagine sexuality in policymaking.

\section{Recognition and Redistribution}

In Nancy Fraser and Judith Butler's conversation about recognition and redistribution politics towards social justice, published in New Left Review (Fraser, 1995) and Social Text (Butler, 1997), they also discussed the impact of such radical politics on people with non-normative sexualities. Fraser argued that discrimination against gays and lesbians is always about recognition, rather than economic redress (1995, p. 77). Challenging that argument, Butler asked: "Is it only a matter of 'cultural' recognition when non-normative sexualities are marginalized and debased, or does the possibility of a livelihood come into play?" (1997, p. 273). This inquiry impacts how we conceive of trans discrimination, as it questions whether it is only a matter of cultural recognition. Butler immediately added: "And is it possible to distinguish, even analytically, between a lack of cultural recognition and material oppression, when the very definition of legal 'personhood' is rigorously circumscribed by cultural norms that are indissociable from their material effects?" (1997, p. 273). For people with non-normative gender and sexualities, recognition and redistribution problems are thus always already paired, 'bivalent.' Accordingly, it can be argued that the mere existence of trans people has been constructed as impossible (Stryker, 2017). After all, the meanings, norms, and values attached to trans lives not only determine their own status as human beings, but also their material access to resources (Spade, 2011; Stryker, 1994).

Going back to the genesis of the debate, Nancy Fraser (1995, p. 72) analyzed the necessary conditions for radical politics, articulating an analytical distinction between a politics of recognition and one of redistribution: Recognition politics seek to establish subordinated groups as "full partners of social life" (Fraser, 2000, p. 113), targeting the cultural injustice through which those social groups have been negatively valued. Therefore, the state must create policies that grant equal status. Fraser also connects the recognition-redistribution distinction to identity; therefore, recognition politics tend to promote a differentiation of social groups that reinforces identity politics (Garcerán, 2016, p. 11), creating a new political subject, such as trans individuals. One prototypical group that embodies recognition struggles are LGBTI+ individuals, and, as I will argue, Spain's trans-specific and LGBTI+antidiscrimination policies can be understood as a relevant source of recognition.

Redistribution politics, on the other hand, targets economic injustice, which is rooted in one's relation to the market or the means of production (Fraser \& Honneth, 2003, p. 14). This politics argues that, since capitalist societies like Spain deprive some groups, the state must offer them some kind of restoration so that they may achieve similar standards of citizenship. The two kinds of politics are intertwined, though, as Fraser explains that people who have a despised sexuality "face injustices of misrecognition requiring remedies of recognition" (Fraser, 1995, p. 78). Recognition and redistribution are deeply intertwined, reinforcing each other dialectically while remaining meaningfully distinct (Fraser, 1995, p. 79).

I argue that social justice for transgender people thus involves recognition of their needs, as well as economic redistribution. Despite the fact a national law (3/2007) now grants transgender people the right to change their sex registration (Spanish Government, 2007), the state still institutionalizes unfair norms by restricting trans individuals to a psychopathological category. This contributes to the existing economic segregation. Redistribution cannot succeed unless joined by struggles for cultural change aimed at reformulating the 
value of trans people' participation in society. Likewise, if recognition claims for trans individuals are not linked to economic redistribution, they become merely symbolic.

While neither Fraser nor Butler specifically mentioned transgender people, the reference to 'despised sexualities' certainly includes them. Notwithstanding, their discussion on sexuality and political economy can be criticized for being sutured to kinship forms typically associated with gay and lesbian politics (Hemmings, 2012 , p. 124). Both authors see sexuality through the hetero/homosexual divide, overstating the transgressive or coopted nature of particular sexual subjects (Hemmings, 2012, pp. 123-124). Trans rights, on the other hand, are linked to the right to have a sex and name registration other than the one assigned at birth, as well as access to basic citizenship rights such as health and employment.

Acknowledging these limitations, my goal is to assess the extent of recognition-redistribution actions in Spanish transgender policies and the role imagination plays in securing sexual subjects' relationship to the political economy (Hemmings, 2012, p. 122). For my analysis, I define recognition as instances in which state institutions acknowledge the needs of trans people and articulate public actions to improve the status quo. Usually, this implies the production of a certain transgender identity in different political realms, such as governmental declarations against discrimination, visibility campaigns in public transportation, the establishment of procedures in education and labor markets to allow trans people to transition, permission to change one's name and sex on documents, and access to segregated spaces, among others. Recognition implies the existence of a cultural domination in which some individuals are rendered invisible and lacking respect (Fraser, 1995, p. 71). Recognition politics thus promote a logic of antidiscrimination and aim to create trans-specific policies (such as the regional laws analyzed herein) and services (such as the genderidentity units in certain Spanish hospitals).

Another take on recognition justice is to focus on the barriers trans people face in society; they may not be recognized as 'particular individuals,' yet they nevertheless face 'particular barriers' (Fernández-Garrido, 2017). In terms of participation in the labor market, for example, recognition would imply not only a declaration that discrimination is wrong, but an analysis of the obstacles trans people face. It would examine how trans people are constructed as troublesome, unfit, and devoid of skills, thereby making companies skeptical about their capability of performing standard business practices.

The entanglement of recognition and redistribution becomes visible in public health services, since acknowledging transphobic obstacles must lead not only to their removal, but also to compensation. Such barriers include the lack of acknowledgement that all health technologies and treatments for trans people were designed for, and are also accessible to, cis people. Instead, rather than aiming for specific bodies, the self-determination approach to trans health promotes assistance in the form of general services. Compensation can include the use of counter-geographies, spaces in which oftenexcluded voices can become experts, and identifying the intersectional obstacles in place (Fernández-Garrido, 2017, p. 15).

When it comes to redistribution justice for trans people, state actions compensate for structural situations of discrimination, such as the historical prosecution of non-normative sexualities under the Francoist dictatorship (1939-1975) or the material difficulties of having a livable life. This compensation becomes a positive action that aims to economically restore trans individuals in certain circumstances. As socioeconomic injustice for trans people generally implies what Fraser calls economic marginalization (poorly paid or lacking jobs) and deprivation of an adequate material standard of living (1995, p. 70), the most common example of redistribution is the 'trans quota': protected employment, direct contracts, or improving transgender people's training to enter the labor force. In Buenos Aires, Argentina, such a trans quota reserves $1 \%$ of public employment for trans people (Government of Argentina, 2015). This type of quota has been imitated in Spanish regions like Aragón. In Uruguay, the government is currently paying a compensation to trans people who were prosecuted and born before 1975 (Government of Uruguay, 2018). Another example is the 'transition period,' a paid work leave similar to those for pregnancy, illness, mourning, or birth. This measure has not yet been applied but can be restorative for the bodily processes involved in transitioning.

\section{Methodology}

My qualitative research is based on the analysis of regional policies targeting trans people in Spain (ten antidiscrimination and six trans-specific), along with twenty-one semi-structured interviews with relevant policymakers (civil servants and politicians) and activists, conducted in December 2019. My basic research question is: What makes a 'good' regional trans policy? Drawing on the analytical concepts of recognition and redistribution, I conducted a theoretically informed analysis of the policies, guiding the interviews with stakeholders. Combining both types of data helped me to understand the quality of the policy by identifying criteria, including the laws' design, current status, and degree of implementation, and the problems and challenges trans people still face.

My criteria to assess the quality of trans legislation were informed by the theoretical discussions above. Firstly, quality involves a balance between recognition and redistribution actions, which contributes to reducing the disenfranchisement of trans individuals. Following Butler's insight that trans problems are bivalent and Fraser's view on recognition and redistribution's intertwinement in real life, I use the recognitionredistribution balance as a way to assess these laws' usefulness and transformative impact. 
Secondly, this analysis has been also inspired by Andrea Krizsan and Emanuela Lombardo (2013, p. 78) discursive approach to assessing the quality of genderequality policies. Accordingly, my assessment analyzes both the laws' content and the issues linked to their policy and implementation processes (here making use of Krizsan and Lombardo's understandings of 'empowerment' and 'transformation'; 2013, pp. 78-79). Empowerment has two dimensions: autonomy (freedom to make life choices, such as self-determining one's transition process) and authority (participation in decision-making; Krizsan \& Lombardo, 2013, p. 79). Transformation, in Kriszan and Lombardo's sense, captures the incremental progress in a given context, so should not be mistaken for an absolute criterion (Krizsan \& Lombardo, 2013, pp. 86-87).

Thirdly, I ensured that interviewees also described their own criteria, which I then incorporated. After all, in addition to highlighting the problems and resistances that emerge, my goal is to map trans regional policies in terms of their quality, so my assessment is multidimensional, but also context-dependent. It is a political process under construction, rather than just an outcome.

I connected my analysis of the discursive representations in the regional laws concerning LGBTI+ and trans rights (see Table 2) to a critical frame analysis, as proposed by Lombardo, Meier, and Verloo (2009). This analysis reveals the dominant representations of trans rights, producing a certain understanding of what trans means, what problems they face, and thus what solutions the state is proposing (Bacchi, 2009). This analysis does not include an in-depth description of the regional context, nor the process by which these regional laws are promoted under certain logics and representations in a given political time.

The interviewees were selected based on their relationship to the respective law's creation process or subsequent application in each region. For some regions, I used the snow-ball technique to identify interviewees using the stakeholders' network (Charmaz, 2006). Because the 21 selected stakeholders gained privileged insights into the problems of trans people in Spain through their work, activism, and/or personal experiences, their accounts contribute to an understanding of the current challenges regarding policymaking for trans individuals (Table 1). The interview questions were organized into three areas: 1 ) involvement in the regional transgender policymaking process; 2) perspectives on the implementation of the transgender policies; and 3 ) the current challenges of transgender individuals in their region. The interviews each lasted approximately 45 minutes. They have been transcribed, analyzed, and compared (Bogner, Littig, \& Menz, 2009). Interestingly, despite being well-known people, often appointed politicians, some of the interviewees preferred to remain anonymous, and accordingly only their region will be used to identify them.

\section{Legislating Trans Rights in Spain}

During Pedro Sanchez's administration (2018-2019), two national policy drafts were passed regarding LGBTI+ antidiscrimination and transgender rights, but neither draft ever became law. During his inauguration speech in

Table 1. Spanish regional LGBTI+ antidiscrimination and trans-specific legislation analyzed per region, type of law, and interviews conducted.

\begin{tabular}{|c|c|c|c|}
\hline \multirow[b]{2}{*}{ Region } & \multirow[b]{2}{*}{ Type of law and year } & \multicolumn{2}{|c|}{ Interviews } \\
\hline & & Activists & $\begin{array}{l}\text { Civil servants } \\
\text { and politicians }\end{array}$ \\
\hline Andalusia & Antidiscrimination (2017) and Trans-specific (2014) & 1 & 1 \\
\hline Aragon & Antidiscrimination (2018) and Trans-specific (2018) & 2 & 1 \\
\hline Balearic Islands & Antidiscrimination (2016) & & 1 \\
\hline Basque Country & Trans-specific (2019), modifies the 2012 law & 2 & \\
\hline Canary Islands & $\begin{array}{l}\text { Trans-specific (2014). Draft law currently in process } \\
\text { to replace the current law }\end{array}$ & 1 & 1 \\
\hline Catalonia & Antidiscrimination 2014 & 1 & 1 \\
\hline Extremadura & Antidiscrimination 2014 & 2 & \\
\hline Galicia & Equal Treatment (2014), first LGBTI+ policy passed & 2 & 1 \\
\hline Madrid & Antidiscrimination (2016) and Trans-specific (2016) & 1 & \\
\hline Murcia & Antidiscrimination (2016) & 1 & \\
\hline Navarre & Antidiscrimination (2017) & 1 & \\
\hline Valencia & Trans-specific (2017) and Antidiscrimination (2018) & 1 & \\
\hline
\end{tabular}


January 2020, Sánchez announced the intention to pass a new trans law, but it is still unclear how the coalition government of Podemos and the Socialist Party will reform the 2007 law regulating the modification of people's sex in the national registry (Spanish Government, 2007).

In the meantime, I will focus on Spanish regional policies approved within the last decade that concern the discrimination of LGBTI+ or transgender people specifically, first tackling the types of laws and their contents, then the recognition/distribution actions, along with the terms used.

\subsection{Type of Law and Content}

Most regions have legislation specifically concerning transgender people (see Table 1), promoted after the narrow scope and limitations of the national legislation that grants transgender people the right to change their name and sex on all documents. Some regions have both types of laws (Andalusia, Aragon, Madrid, and Valencia), while other regions have either a single anti-discrimination law for LGBTI+ people (the Balearic Islands, Catalonia, Extremadura, Galicia, Murcia, and Navarre) or a trans-specific law (the Canary Islands and the Basque Country). Still other regions have had political debates that produced draft bills which ultimately never materialized into laws (Asturias, Cantabria, Castilla-Leon, and La Rioja).

It should be noted here that the specific laws currently on the books are a result of the struggles of LGBTI+ and trans organizations, as a Catalonian stakeholder highlighted: "None of the laws is a result of the political parties' initiative; they were conceived by the movement. Politicians did not have clear LGBTI+ politics."

But having the type of law is not always decisive in terms of the extent to which trans rights are granted. Extremadura, for example, only has an antidiscrimination law, yet according to the activists interviewed, "the trans actions and protocols are fully implemented, similarly to regions with a trans-specific law." Similarly, a region having more laws is not always an indication of more rights being granted. Catalonia, for instance, has only one policy on antidiscrimination, but it grants an important number of rights and is widely implemented. Andalusia has two laws that are also widely implemented, while in other regions the implementation is ongoing and slow. Therefore, both the laws' content and implementation must be analyzed in order to assess their quality.

Catalonia and Andalusia have set an example of promoting rights within the areas of health-care provision and prosecution of discrimination, among others. Catalonia introduced LGBTI+ rights regulation throughout the entire administration as a sort of mainstreaming, and Andalusia was the first to claim trans selfdetermination of identity, following the 2011 Argentinian law. These examples paved the road. As the Valencian activist interviewed said: "We looked into other regions, looking for examples." Of course, they also faced resis- tance: "Some politicians underestimated [the number of] trans people, saying we wanted a law for 'only three people,"' an Extremaduran interviewee remarked.

Other regions, however, grant fewer rights. As a civil servant stated, in Galicia "it was the first [such] law in the country; no one knew how to make one," adding, "the existence of the antidiscrimination law is used to stop further law developments. It was never meant to be fully applied." In the Canary Islands, the Socialist government announced a new law substituting the current one, which both activists and policymakers deem insufficient. In the Basque Country, the law was recently amended to include a brief statement on the depathologization and self-determination of trans people.

The laws analyzed here have been passed by governments of different colors, including conservatives, nationalists, socialists, and left-wing parties. Political will is decisive for the design and implementation of transpositive laws, giving meaning to what equal treatment, depathologization, and self-determination mean. But most relevantly, they are time-specific: Earlier laws were framed in tune with the national legislation (which inscribed transsexuality as a disorder called 'gender dysphoria'), while later ones (Catalonia, Basque Country, Extremadura) aiming for depathologization, and even more recent ones (Andalusia, Aragon, Balearic Islands, Madrid, Murcia, Navarra, and Valencia) aim for the selfdetermination of transgender people.

These laws include actions on non-discrimination (within the administration, education, health, employment, culture, sports, support for organizations, and international cooperation, among others) and transspecific actions (health, employment, social participation, historical memory, communication, etc.). Lastly, some also include punishing discrimination against LGBTI+ individuals, the creation of institutions and plans, social services, etc. Practically, according to the Andalusian stakeholders interviewed, "some policy areas make a difference, such as health, employment, and youth's rights," whereas for the Catalonian stakeholder, "it is their capacity to punish that was radically new."

Next to the laws passed, most regions, including the ones without a trans or LGBTI+ law, have education and health protocols for trans individuals, aiming to ensure protection against bullying, the possibility of transitioning, and access to medical treatments. These protocols further develop regional legislation, and sometimes "may amplify and improve what was stated in the law," as an activist said about the Canary Islands.

\subsection{Recognition and Redistribution}

Table 2 summarizes the laws' main actions concerning recognition and redistribution (with some examples), along with the main term used in the policy text to describe its narrative (self-determination, depathologization, recognition of rights, non-discrimination, social equality), the health model (offering specific gender- 
Table 2. Spanish regional LGBTI+ antidiscrimination and trans-specific laws (2009-2020).

\begin{tabular}{|c|c|c|c|c|c|c|}
\hline Region & Recognition & Redistribution & Terms used & $\begin{array}{l}\text { Healthcare } \\
\text { model }\end{array}$ & $\begin{array}{l}\text { Capacity to } \\
\text { penalize } \\
\text { discrimination }\end{array}$ & $\begin{array}{l}\text { Party in } \\
\text { office }\end{array}$ \\
\hline $\begin{array}{l}\text { Andalusia } \\
(2014, \\
2017)\end{array}$ & $\begin{array}{l}\text { Recognition of gender } \\
\text { self-determination as } \\
\text { legal status }\end{array}$ & $\begin{array}{l}\text { Positive actions } \\
\text { in employment, } \\
\text { such as tax } \\
\text { exemption } \\
\text { when employing } \\
\text { trans people }\end{array}$ & $\begin{array}{l}\text { Self- } \\
\text { determination } \\
\text { (first region } \\
\text { to use it) }\end{array}$ & $\begin{array}{l}\text { Proximity } \\
\text { health-care } \\
\text { services and } \\
\text { hospital unit }\end{array}$ & Yes & $\begin{array}{l}\text { Socialist } \\
\text { Party }\end{array}$ \\
\hline $\begin{array}{l}\text { Aragon } \\
(2018)\end{array}$ & $\begin{array}{l}\text { Services for LGBTI+ } \\
\text { and trans people. } \\
\text { Funding for } \\
\text { organizations. } \\
\text { Including a non-binary } \\
\text { gender category on } \\
\text { documents. } \\
\text { Assistance for } \\
\text { homeless trans adults } \\
\text { and youth, asylum } \\
\text { seekers, and migrants. } \\
\text { Development } \\
\text { cooperation. }\end{array}$ & $\begin{array}{l}\text { Public } \\
\text { employment } \\
\text { (1\% of protected } \\
\text { employment) } \\
\text { and grants to } \\
\text { hire trans } \\
\text { people. }\end{array}$ & $\begin{array}{l}\text { Self- } \\
\text { determination }\end{array}$ & $\begin{array}{l}\text { Proximity } \\
\text { health care } \\
\text { and hospital } \\
\text { unit, with im- } \\
\text { plementation } \\
\text { problems }\end{array}$ & Yes & $\begin{array}{l}\text { Socialist } \\
\text { Party and } \\
\text { CHA }\end{array}$ \\
\hline $\begin{array}{l}\text { Balearic } \\
\text { Islands } \\
(2016)\end{array}$ & $\begin{array}{l}24 \mathrm{~h} \text { Help Line. } \\
\text { Pilot program for the } \\
\text { use of the non-binary } \\
\text { choice in bureaucratic } \\
\text { arrangements. }\end{array}$ & $\begin{array}{l}\text { Direct funding of } \\
\text { vaginoplasty } \\
\text { surgery for trans } \\
\text { women, in order } \\
\text { to reduce the } \\
\text { 21-person-long } \\
\text { waiting list of } \\
\text { eight years }\end{array}$ & $\begin{array}{l}\text { Self- } \\
\text { determination }\end{array}$ & $\begin{array}{l}\text { New health } \\
\text { protocol, } \\
\text { developed } \\
\text { with trans } \\
\text { organizations. }\end{array}$ & Yes & $\begin{array}{l}\text { Socialist } \\
\text { Party, } \\
\text { Podemos, } \\
\text { Més x } \\
\text { Mallorca y } \\
\text { Més per } \\
\text { Menorc }\end{array}$ \\
\hline $\begin{array}{l}\text { Basque } \\
\text { Country } \\
(2019)\end{array}$ & $\begin{array}{l}\text { Amplifies the national } \\
\text { legislation of } 2007\end{array}$ & & $\begin{array}{l}\text { Depatholo- } \\
\text { gization }\end{array}$ & Hospital unit & No & $\begin{array}{l}\text { PNV and } \\
\text { Socialist } \\
\text { Party }\end{array}$ \\
\hline $\begin{array}{l}\text { Canary } \\
\text { Islands } \\
(2014)\end{array}$ & $\begin{array}{l}\text { Trans women victims } \\
\text { of violence are } \\
\text { granted the same } \\
\text { rights as cis women, } \\
\text { and are not required } \\
\text { to have their ID } \\
\text { changed. }\end{array}$ & & $\begin{array}{l}\text { Non- } \\
\text { discrimination }\end{array}$ & $\begin{array}{l}\text { Health } \\
\text { assistance } \\
\text { with specific } \\
\text { units at } \\
\text { hospitals using } \\
\text { the national } \\
\text { law's logic of } \\
\text { diagnosis and } \\
\text { pathologiza- } \\
\text { tion }\end{array}$ & No & $\begin{array}{l}\text { Coalición } \\
\text { Canaria and } \\
\text { Socialist } \\
\text { Party }\end{array}$ \\
\hline $\begin{array}{l}\text { Catalonia } \\
(2014)\end{array}$ & $\begin{array}{l}\text { Public servants must } \\
\text { act against } \\
\text { discrimination. } \\
\text { Depathologization of } \\
\text { trans identities and } \\
\text { service provision. } \\
\text { Widespread action by } \\
\text { the Catalonian } \\
\text { administration against } \\
\text { LGBTI+ phobia. }\end{array}$ & $\begin{array}{l}\text { Employment } \\
\text { actions for trans } \\
\text { people. } \\
\text { Access to } \\
\text { assisted } \\
\text { reproductive } \\
\text { treatment for } \\
\text { lesbians and } \\
\text { single women. }\end{array}$ & $\begin{array}{l}\text { Depatholo- } \\
\text { gization } \\
\text { (which is not } \\
\text { defined) }\end{array}$ & $\begin{array}{l}\text { Innovative } \\
\text { proximity } \\
\text { health service, } \\
\text { TRANSIT, } \\
\text { which } \\
\text { becomes an } \\
\text { example. }\end{array}$ & $\begin{array}{l}\text { Yes (first } \\
\text { one) }\end{array}$ & $\begin{array}{l}\text { Iniciativa } \\
\text { Per } \\
\text { Catalunya, } \\
\text { Socialist } \\
\text { Party and } \\
\text { Esquerra } \\
\text { republicana. }\end{array}$ \\
\hline
\end{tabular}


Table 2. (Cont.) Spanish regional LGBTI+ antidiscrimination and trans-specific laws (2009-2020).

\begin{tabular}{|c|c|c|c|c|c|c|}
\hline Region & Recognition & Redistribution & Terms used & $\begin{array}{l}\text { Healthcare } \\
\text { model }\end{array}$ & $\begin{array}{l}\text { Capacity to } \\
\text { penalize } \\
\text { discrimination }\end{array}$ & $\begin{array}{l}\text { Party in } \\
\text { office }\end{array}$ \\
\hline $\begin{array}{l}\text { Extremadura } \\
\text { (2014) }\end{array}$ & $\begin{array}{l}\text { Civil servants must act } \\
\text { against discrimination. } \\
\text { Transversalisation of } \\
\text { LGBTI+ rights in all } \\
\text { institutions, including } \\
\text { rural areas, with a } \\
\text { positive impact on trans } \\
\text { youth. } \\
\text { Services for trans } \\
\text { people. }\end{array}$ & $\begin{array}{l}\text { Access to } \\
\text { assisted } \\
\text { reproductive } \\
\text { treatment for } \\
\text { lesbians and } \\
\text { single women. }\end{array}$ & $\begin{array}{l}\text { Depatho- } \\
\text { ligization. }\end{array}$ & $\begin{array}{l}\text { Proximity } \\
\text { services along } \\
\text { with a gender } \\
\text { unit that is } \\
\text { decentralised } \\
\text { in all } \\
\text { provinces. } \\
\text { Problems of } \\
\text { implementa- } \\
\text { tion }\end{array}$ & $\begin{array}{l}\text { Yes, but it } \\
\text { has not } \\
\text { been } \\
\text { imple- } \\
\text { mented. }\end{array}$ & PP \\
\hline $\begin{array}{l}\text { Galicia } \\
(2014)\end{array}$ & $\begin{array}{l}\text { First law, and in a } \\
\text { conservative region, } \\
\text { that establishes equal } \\
\text { treatment with some } \\
\text { symbolic actions. }\end{array}$ & & $\begin{array}{l}\text { Equal } \\
\text { treatment } \\
\text { and non- } \\
\text { discrimination }\end{array}$ & $\begin{array}{l}\text { Hospital (not } \\
\text { specific unit) }\end{array}$ & No & $\mathrm{PP}$ \\
\hline $\begin{array}{l}\text { Madrid } \\
\text { (2016) }\end{array}$ & $\begin{array}{l}\text { Laws are innovative and } \\
\text { contain new rights } \\
\text { (reproductive rights, } \\
\text { training for } \\
\text { professionals, research, } \\
\text { assistance for } \\
\text { vulnerable trans people) } \\
\text { in accordance with } \\
\text { other regional laws, but } \\
\text { have not been fully } \\
\text { developed. } \\
\text { Trans women victims of } \\
\text { violence are granted } \\
\text { same rights as cis } \\
\text { women. }\end{array}$ & $\begin{array}{l}\text { Some } \\
\text { employment } \\
\text { actions for trans } \\
\text { people }\end{array}$ & $\begin{array}{l}\text { Self- } \\
\text { determination }\end{array}$ & $\begin{array}{l}\text { Proximity } \\
\text { health care } \\
\text { services and } \\
\text { hospital unit }\end{array}$ & $\begin{array}{l}\text { Yes, but it } \\
\text { has not } \\
\text { been im- } \\
\text { plemented }\end{array}$ & PP \\
\hline $\begin{array}{l}\text { Murcia } \\
\text { (2016) }\end{array}$ & $\begin{array}{l}\text { Trans women victims of } \\
\text { violence are granted } \\
\text { same rights as cis } \\
\text { women. }\end{array}$ & $\begin{array}{l}\text { Employment } \\
\text { measures (not } \\
\text { implemented). } \\
\text { Easier } \\
\text { requirements for } \\
\text { the Minimum } \\
\text { Income } \\
\text { Allowance. }\end{array}$ & $\begin{array}{l}\text { Non- } \\
\text { discrimination }\end{array}$ & $\begin{array}{l}\text { There is not } \\
\text { health } \\
\text { protocol, the } \\
\text { intervention is } \\
\text { pathologizing }\end{array}$ & $\begin{array}{l}\text { Yes, but it } \\
\text { has not } \\
\text { been im- } \\
\text { plemented }\end{array}$ & $\mathrm{PP}$ \\
\hline $\begin{array}{l}\text { Navarre } \\
\text { (2017) }\end{array}$ & $\begin{array}{l}\text { Funding for LGBTI+ } \\
\text { organizations and } \\
\text { events. } \\
\text { Action plan and } \\
\text { diagnosis of LGBTI+ } \\
\text { realities. } \\
\text { LGBTI+ Board. } \\
\text { Civil Servants must act } \\
\text { against discrimination. } \\
\text { Development } \\
\text { cooperation. } \\
\text { High participation in the } \\
\text { policy-making process. }\end{array}$ & $\begin{array}{l}\text { Promotion of } \\
\text { employment } \\
\text { plans. }\end{array}$ & $\begin{array}{l}\text { Social } \\
\text { Equality/equal } \\
\text { rights }\end{array}$ & $\begin{array}{l}\text { Proximity } \\
\text { health care } \\
\text { services and } \\
\text { hospital unit. } \\
\text { Access to } \\
\text { health care } \\
\text { with a non- } \\
\text { pathological } \\
\text { perspective, } \\
\text { with imple- } \\
\text { mentation } \\
\text { problems. }\end{array}$ & $\begin{array}{l}\text { Yes, but it } \\
\text { has not } \\
\text { been im- } \\
\text { plemented }\end{array}$ & $\begin{array}{l}\text { Geroabai, } \\
\text { EH Bildu, } \\
\text { Podemos, } \\
\text { IE. }\end{array}$ \\
\hline
\end{tabular}


Table 2. (Cont.) Spanish regional LGBTI+ antidiscrimination and trans-specific laws (2009-2020).

\begin{tabular}{|c|c|c|c|c|c|c|}
\hline Region & Recognition & Redistribution & Terms used & $\begin{array}{l}\text { Healthcare } \\
\text { model }\end{array}$ & $\begin{array}{l}\text { Capacity to } \\
\text { penalize } \\
\text { discrimination }\end{array}$ & $\begin{array}{l}\text { Party in } \\
\text { office }\end{array}$ \\
\hline $\begin{array}{l}\text { Valencia } \\
(2017, \\
2018)\end{array}$ & $\begin{array}{l}\text { Each region has a } \\
\text { service to promote } \\
\text { LGBTI+ and trans rights. } \\
\text { Trans Board. } \\
\text { Trans Consultation } \\
\text { Board. }\end{array}$ & $\begin{array}{l}\text { Employment } \\
\text { actions (tax } \\
\text { exemption and } \\
\text { promotion of } \\
\text { public contracts } \\
\text { with companies } \\
\text { that have trans } \\
\text { employees) }\end{array}$ & $\begin{array}{l}\text { Self- } \\
\text { determination }\end{array}$ & $\begin{array}{l}\text { Healthcare } \\
\text { assistance has } \\
\text { expanded to } \\
\text { all provinces, } \\
\text { with imple- } \\
\text { mentation } \\
\text { problems }\end{array}$ & Yes & $\begin{array}{l}\text { Socialist } \\
\text { Party } \\
\text { - Podemos } \\
\text { Compromis- } \\
\text { EUPV }\end{array}$ \\
\hline
\end{tabular}

identity units at hospitals and/or a form of proximity health-care in the already existing primary health-care centers), the capacity to penalize discrimination, and the party/ies in office when the law was passed.

All the laws analyzed can be interpreted as a kind of social recognition since they establish or continue the entry of sexual and gender issues onto the mainstream agenda trough a concrete language (see first column of Table 2). As they open a space for continuous dialogue with the administration, I consider the creation of LGBTI+ and trans participatory bodies in most regions a form of recognition. Other forms of recognition include laws that promote LGBTI+ and/or trans information and assistance services, LGBTI+ discrimination observatories, and other services run by NGOs.

Yet my interviewees remarked that these new services and institutional bodies generally have low budgets and insufficient staff, "turning their work into a sort of activism," commented a Balearic Islands civil servant. The interviewee added that "the policies are often ambitious, and their budgets are too low," which may result in a rather modest impact. In the Balearic Islands, two public workers oversee the coordination of all LGBTI+ politics. Relevant actions included in the laws-such as sanctioning discrimination with fines (see fifth column), training public servants, and more widely promoting the rights and duties granted by the policies-are often underdeveloped. Laws often are not specific enough on how the proposed actions will be carried out, using the legal formula of the future "further development of a regulation." According to the Catalonian interviewee, however, the local "law was born with a deadly trap, announcing that a sanctioning institution and a non-discrimination law will be created in the future," which then never ends up happening. Again, as several stakeholders mentioned, policies are resulting in a recognition of rights that is not always followed by concrete actions or that is insufficiently funded.

As shown in Table 2's second column, nine regional laws include redistribution actions (Andalusia, Aragon, the Balearic Islands, Catalonia, Extremadura, Madrid, Murcia, Navarra, and Valencia). Some laws also include positive actions in employment, actions that can be non- specific (e.g., Murcia) or concrete with tax exemption for employers (e.g., Andalusia), promoting public agreement with companies that hire trans workers (Valencia), or promoting protected employment (e.g., Aragon or Catalonia). The laws include some intersectional description of trans lives, and some specific actions are embedded in most of the policies analyzed (mostly regarding age, social class, gender, disability, and homelessness, among others). In general, the implementation of these positive actions in employment is slow, according to the policymakers and activist interviewed: "In some areas, it is just not happening," said the Valencian stakeholder.

Table 2's third column describes the main term used in the laws. Three regions use depathologization (Basque Country, Catalonia, and Extremadura), five use self-determination (Andalusia, Aragon, Balearic Islands, Madrid, and Valencia), and the rest use equal treatment (Galicia), social equality (Navarra), or non-discrimination (Canary Islands). Depathologization was a term coined by trans organizations while advocating internationally on platforms to challenge the framework of transsexuality (Suess, 2018). After 2011, activists also used selfdetermination. Both terms are associated with concrete demands to make decisions about one's own body, and to access basic citizenship rights. The language and definitions used in the policy texts are relevant: They create new legal realities and allow the emergence of political subjects-such as intersex people, transgender children and their families, or non-binary people-who become the subjects of rights. As interviewees highlighted, depathologization and self-determination are not just words within a law, but rather markers showing that these laws are "claimed as our own" (Valencian stakeholder), "achieved after long-term activism" (Catalonian stakeholder), and "meant to change realities" (Basque stakeholder). By choosing such new framing, some of these laws achieve rights that are radically new in Spain: "Having legislation in Andalusia that establishes a younger age than other regions, 14, at which trans children are granted access to cross-sex hormone therapy is life-changing and was unimaginable before the self-determination turn," said an activist in Andalusia. Interestingly, transgender children's needs are included 
in these laws through the activism of organizations of their families (Platero, 2014).

Most laws analyzed introduce a rather heterogeneous glossary of definitions on sexuality and discrimination. These laws face the challenge of an administrative language that is deeply rooted in binarism and heterosexism. Some laws reference the repression under the Francoist dictatorship, while others refer to international and national legislation as a source of legitimation. To this extent, more recent policies benefit from the experience of other regions, being able to choose from different laws; the latest laws have also been introducing a more comprehensive understanding of transgenderism, including, for example, non-binary identities.

This language can be analyzed along the proposed health model (see the next column in Table 2), since that wording also has an impact on how to design policymaking. In the appearance of these policies over time, access to public health services clearly shifts from pathologizing gender units at hospitals towards a model of proximity health provision based on trans individuals' capacity to choose their own transition path (now offered in Andalusia, Balearic Islands, and Catalonia). The use of the term self-determination thus is a political approach that materializes in a previously non-existent health service. The use of this concept is linked to the implementation of proximity health care, whereas other regions use other concepts and health provision based on trans-specific units, which have had pathologizing practices (Basque Country, Canary Islands, Galicia, and Murcia). Despite the introduction of this innovative self-determination model, its implementation has often faced resistance from professionals who continue subjecting people to a process of classification, humiliation, and denial of rights, and a general undervaluation of trans people's needs. Sometimes, it can be the case that a transformative term is used even while pathologizing practices, along with practical barriers to accessing proximity health care, are still present: this is the case in Aragon, Navarra, and Valencia.

\section{Assessing Quality in Spanish Trans Policies with Policymakers and Activists}

In the discussions with policymakers and activists about what they consider a quality trans law, there is a consensus about "having an impact on trans people's wellbeing and expansion of their existing rights," as the Valencian activist put it. According to the Catalonian activist, "laws have made an impact, including more rights, sanctioning discrimination, and creating specific bodies for political participation with the public administration." Trans-positivity can be traced in the number and quality of rights granted under the discursive umbrella of self-determination and depathologization, which for our interviewees implies recognition (through proximity health services, children's rights, participatory boards, services for trans and/or LGBTI+ people, among others), but also redistribution (mostly employment, compensation for elder trans and LGBTI+ people discriminated against under the dictatorship, and direct funding of surgeries). To different degrees, such a bivalent approach that tackles empowerment, transformation, and well-being is present in the laws from Andalusia, Aragon, Balearic Islands, Catalonia, Extremadura, Madrid, Navarra, and Valencia.

Moreover, research participants indicated that quality is also associated with the participation of trans organizations. As I mentioned, Catalonian stakeholders credited "activists for the achievement of trans laws." This kind of participation ('authority' in Krizsan and Lombardo's work) can be measured by such organizations' overall engagement in policymaking and the extent to which participatory boards are created, functioning, and perceived as useful. In Extremadura, an activist sadly stated that "the LGBTI+ Body created was useless, due to the participation rules that allowed for companies and non-NGO groups that have different economic interests."

The policymaking process has resulted in empowerment due to a double literacy: the policymaking literacy of activists who become experts ("not in my wildest dreams did I picture myself being part of policymaking," said an activist from Madrid); and, for politicians, a literacy on non-normative sexualities and trans experiences, according to the interviewees ("we were not aware of the many nuances that affected trans people's lives," said a civil servant in the Balearic Islands). Not all organizations were involved in the policymaking process, often "opting instead to consult with those that already participate in public funding," as the same Madrid activist stated. Furthermore, activists dealt with resistance in the political parties' negotiations, often having to use persuasion techniques and press for certain actions. In addition, the follow-up in implementation is considered a weak area for stakeholders, who are now seeing how, in some regions, the next legislature brings in new political parties or leaders of the same party that are not equally committed to the law.

Likewise, looking at the implementation process, interviewees remarked on the resistance found in all regions, especially concerning how trans rights are materialized in proximity health services, training of public servants, and education programs (which I consider recognition actions), but also in employment programs (the most common redistribution action). Interviewees identified specific barriers in Aragon, Extremadura, Navarra, and Valencia. For instance, in Valencia, "public health centers often do not see trans patients, despite what the law states, arguing that they do not have the training or the will to do so." Other commonly mentioned problems are insufficient funding or resources, lack of precision in the law or future procedures, lack of political will, and governmental changes. In Andalusia, although "the law is $90 \%$ implemented, the precise protocols to develop every article are often missing, for instance in regard to supporting trans youth," said a local activist. 
Drawing from the discussion about the quality of trans laws with policymakers and activists, but also using Krizsan and Lombardo's insights, laws can be analyzed in terms of the extent to which the current discrimination of trans people is transformed. Transformation, according to Fraser (1995, pp. 82-83), restructures the underlying generative framework, redressing disrespect and transforming the underlying (transphobic) culture. Assessing the degree of transformation these laws reached generates a differentiation of such policies. Stakeholders interviewed rank the highest the policies that focus on the self-determination and depathologization of trans people, and lowest the laws that made inclusion, equal treatment, and social quality their goals.

On the one hand, pursuing inclusion, equal treatment, and non-discrimination seems rational and creates less resistance, but these are short-term goals that individualize transphobia. These policies tend to create an individual logic of merits, so only some transgender people can access these rights. This is the case for the national transgender legislation 3/2007 (Spanish Government, 2007), which set restrictive requirements in order to change one's name and sex on IDs and documents (being Spanish and an adult, not having 'other' disorders, qualifying for 'gender dysphoria disorder,' and undergoing two years of hormone treatment, with exceptions for elderly individuals with a medical condition; Platero, 2011). Therefore, those individuals who do not fit or do not want to fit those requirements are left out. This meritocracy approach can also be traced in the laws passed in the Basque Country, the Canary Islands, Galicia, and Murcia. Transformation, in Fraser's sense, takes place in relation to an existing context and, given that Spain is a country with strong regional inequalities, the heterogeneity of trans and LGBTI+ policies contributes to reinforcing such inequalities.

To some activists, it is important that discriminatory acts be punished by fines, along with qualification as crimes already existing in the penal code (Andalusia, Aragon, Balearic Islands, Catalonia, Extremadura, Madrid, Murcia, Navarra, and Valencia). As the Catalonian activist put it, "the Catalonian law is innovative by punishing discrimination, although its application in practice is difficult with only 14 actual sanctions." Therefore, despite the symbolic relevance of this punitive approach, "in practice, it is not working," according to the same activist.

On the other hand, some policymakers take further steps, introducing the capacity of the trans individual to decide their own transition process (what Krizsan \& Lombardo, 2013, call 'autonomy') and emphasizing transphobia rather than the short-term and individual approach. Tackling transphobia requires a social, structural transformation, making this a long-term goal. Such a transformation requires a cultural and social recognition change that makes discrimination reproachable, similar to what has happened with violence against women in Spain. These changes not only concern transgender peo- ple's sense of belonging, affiliation, and self, but the entirety of society (Fraser, 1995, p. 83).

Thinking through transformation, the Fraser-Butler discussion on cultural recognition and economic redistribution becomes useful again. The social recognition granted by these policies is important, since it creates the possibility of having a life worth living, something many generations of people with non-normative identities have lacked. As illustrated, Spanish trans policies rank high in terms of social recognition-perhaps no wonder considering the concurrent high global cultural interest in trans realities. But achieving transformation also implies destabilizing group identities and differentiations, instead of only revaluing and affirming devalued group identities (Fraser, 1995, pp. 82-83). It requires the mobilizing a certain social group, trans individuals, that contributes to de-stabilizing the trans/cis dichotomy in the process.

Recognition always has to be understood in relation to redistribution. So far, stakeholders mostly imagined redistribution as employment programs: "Employment is what trans people really need," said an activist in Aragon. However, trans people are not a homogenous collective at risk of social exclusion: instead, due to a combination of factors, some trans people experience more employment problems (Coll-Planas \& Missé, 2018, p. 64). Following Spade (2011), LGBTI+ anti-discrimination and trans policies can be criticized for their limited capacity to improve living conditions for trans people in the most vulnerable situations, such as trans people in prison, trans refugees, poor trans people, trans people of color, and trans youth. Spade invokes the capacity for transformation by urging us to think of the structural and intersectional dimensions of policymaking, but also remarks that common administrative procedures generate great violence against trans people. Though one can argue that, as transgender laws make it easier for people to change their name and sex on national and social security IDs and to access hormonal treatments in a self-chosen path, they mitigate the impact of transphobic violence. But then again, these actions rely on the individual being able to navigate the oftentransphobic social reality and do not directly tackle their economic marginalization.

Turning back to Fraser (1995, p. 92), we need to "figure out how to finesse the redistribution-recognition dilemma when we situate the problem in this larger field of multiple, intersecting struggles against multiple, intersecting injustices." Although there is some intersectional attention to trans lives, a more precise analysis of the intertwined realities of trans people in Spain needs to be developed in order to begin to imagine redistribution policies. The overemphasis on trans identity politics in Spain diverts attention from the effects of capitalism and wealth inequality (Fraser, Urbieta, \& Navarro, 2016), requiring spaces in which to imagine redistribution politics (Hemmings, 2012, p. 122). 


\section{Conclusions}

Since 2012, trans and LGBTQI+ organizations have struggled to pass 16 regional laws in alliance with different political parties, all the while lacking a consensus on what trans rights mean in policymaking. During this short time, activists and policymakers had to conceptualize what the use of these laws would be, what rights they could grant, and how they could be made. Accordingly, they tried to find inspiration in other international laws and previous Spanish regional laws, directly contacting other policymakers and activists.

It is not a surprise that the inclusion of a new political subject, one who is trying to move away from being defined as a person with a disorder, results in identity politics. Yet the transformation that the trans activists I interviewed demanded can only be achieved once we "sustain a field of multiple, debinarized, fluid and evershifting differences" (Fraser, 1995, p. 83).

The assessment of the quality of these laws is linked to the balance of recognition-redistribution actions, including feminist criteria such as empowerment, transformation, well-being, and-to a certain extent-punishing discrimination. Trans policies in Spain benefit social recognition in policymaking but only promote redistribution for (some) trans individuals in vulnerable situations to a lesser extent, not always achieving a balance. Empowerment, with its double emphasis on autonomy (a shift to a de-pathologization and self-determination models) and authority (participation in the policymaking process) has been a crucial criterion in assessing the quality of trans laws. In this regard, according to the stakeholders interviewed, better-quality trans legislation is linked to self-determination, participatory processes in policymaking, wide implementation, the creation of public bodies and specific services, proximity health services, rights for children, the capacity to penalize discrimination, and further positive actions. Better-quality legislation combines recognition and redistribution in areas that have been identified as transformative by trans organizations (protected employment and funding for surgeries, for instance). Other redistribution policies are yet to be imagined.

So far, when discussing positive actions, the policymakers interviewed only imagine employment actions, leaving out other types of political measures, such as compensation for the discrimination that occurred under Franco's dictatorship, or compensation for long-term disenfranchised trans individuals. Inspired by José Muñoz's acknowledgement that "here and now are not enough," a transformative future for trans people in Spain requires both a queer political imagination (Muñoz, 2009, p. 1) that engages with the political economy and going beyond mere affirmation of trans identities to pursue the deconstruction of the trans-cis dichotomy.

Lastly, the differences found in the regional laws analyzed here produce an asymmetry with regard to the exercise of trans rights that can only be resolved with a na- tional trans law. It remains to be seen whether the current coalition government, amidst its national response to the current COVID-19 pandemic and the campaign of some socialist feminists and academics against trans rights, will be able to achieve the necessary alliances to approve a trans rights law that includes both recognition and redistribution.

\section{Acknowledgments}

This article is possible thanks to the great support received throughout the researching, writing and editing process, especially during as complicated a time as the current health pandemic. Firstly, policymakers and activists were generously willing to share their often-complicated experiences with passing trans legislation in Spain. Secondly, the editors offered unconditional support, exercising a remarkable feminist mentorship. Thirdly, the in-depth analysis of the reviewers greatly improved this article. Lastly, I would like to recognize the vital impact of the Emma Goldman Award (Flax Foundation), which provided valuable support for this project.

\section{Conflict of Interests}

The author declares no conflict of interests.

\section{References}

Álvarez, A. (2020, June 13). Contra el borrado de las mujeres [Against the erasure of women]. Eldiario. Retrieved from https://www.eldiario.es/opinion/ tribuna-abierta/borrado-mujeres_129_6102064. html

Bacchi, C. (2009). Analysing policy: What's the problem represented to be. Frenchs Forest: Pearson.

Bogner, A., Littig, B., \& Menz, W. (2009). Interviewing experts. New York, NY: Palgrave Macmillan.

Butler, J. (1997). Merely cultural. Social Text, 15(3/4), 265-277.

Charmaz, K. (2006). Constructing grounded theory. Thousand Oaks, CA: Sage.

Coll-Planas, G., \& Missé, M. (2018). Identificación de los factores de inserción laboral de las personas trans: Exploración del caso de la ciudad de Barcelona [Identification of the factors influencing the job integration of transgender people: Exploring the case of Barcelona]. OBETS: Revista de Ciencias Sociales, 13(1), 45-68.

Fernández-Garrido, S. (2017). El diagnóstico participativo de las problemáticas que presentan las personas $T L G B Q$ l en salud sexual, reproductiva y derecho al ejercicio de la identidad en el municipio de Madrid [Participatory diagnosis of TLGBQI people's problems related to sexual and reproductive health and their right to exercise their identity in the city of Madrid]. Madrid: Ayuntamiento de Madrid. 
Fraser, N. (1995). From redistribution to recognition? Dilemmas of justice in a 'postsocialist' age. New Left Review, 212, 68-93.

Fraser, N. (2000). Rethinking recognition. New Left Review, 3, 107-120.

Fraser, N., \& Honneth, A. (2003). Redistribution or recognition? A political-philosophical exchange. London: Verso.

Fraser, N., Urbieta, R., \& Navarro, F. (2016). The battle for neoliberal hegemony: An interview with Nancy Fraser. openDemocracy. Retrieved from https://www.opendemocracy.net/en/battle-forneoliberal-hegemony

Garcerán, M. (2016). ¿Qué se reconoce en las políticas de reconocimiento? Una introducción al debate entre Nancy Fraser y Judith Butler [What is recognized in recognition politics? An introduction to the debate between Nancy Fraser and Judith Butler]. In J. Butler \& N. Fraser (Eds.), ¿Reconocimiento o redistribución? Un debate entre marxismo y feminismo [Recognition or redistribution? A debate between Marxism and Feminism] (pp. 7-22). Madrid: Traficantes de Sueños. Government of Andalusia. (2014). Ley integral para la no discriminación por motivos de identidad de género y reconocimiento de los derechos de las personas transexuales [Regional and Comprehensive Law on nondiscrimination on the basis of gender identity and the recognition of the rights of transsexual people] (Law 2/2014). Sevilla: Government of Andalusia.

Government of Andalusia. (2017). Ley para garantizar los derechos, la igualdad de trato y no discriminación de las personas LGTBI y sus familiares [Regional law to guarantee the rights, equal treatment, and nondiscrimination of LGTBI people and their families] (Law 8/2017). Andalusia: Government of Andalusia.

Government of Aragon. (2018). Ley de identidad y expresión de género, e igualdad social y no discriminación [Law regulating gender identity and expression, social equality and non-discrimination] (Law 4/2018). Zaragoza: Government of Aragon.

Government of Argentina. (2015). Cupo trans [Trans quota] (Law 14.783). La Plata: Government of Argentina.

Government of Catalonia. (2014). Ley que garantiza los derechos de lesbianas, gays, bisexuales, transgéneros e intersexuales y para erradicar la homofobia, la bifobia y la transfobia [Regional law to guarantee the rights of lesbian, gay, bisexual, transgender and intersex people and to erradicate homophobia, biphobia and transphobia] (Law 11/2014). Catalonia: Government of Catalonia.

Government of Extremadura. (2015). Ley de igualdad social de lesbianas, gays, bisexuales, transexuales, transgénero e intersexuales y de políticas públicas contra la discriminación por orientación sexual e identidad de género [Regional law on social equality for lesbian, gay, bisexual, transsexual, transgender and intersex people, and on public policies of non- discrimination on the basis of sexual orientation and gender identity] (Law 12/2015). Extremadura: Government of Extremadura.

Government of Galicia. (2014). Ley por la iguadad de trato y la no discriminación de lesbianas, gays, transexuales, bisexuales e intersexuales [Regional law on the equal treatment and non-discrimination of lesbian, gay, transsexual, bisexual, and intersex people] (Law 2/2014). Galicia: Government of Galicia.

Government of Madrid. (2016a). Ley de identidad y expresion de género e igualdad social y no discriminación [Regional law on gender identity and expression, equal treatment and non-discrimination] (Law 2/2016). Madrid: Government of Madrid.

Government of Madrid. (2016b). Ley protección integral contra la LGTBIfobia y la discriminación por razón de orientación sexual e identidad de género [Regional and comprehensive protection law against LGTBIphobia and discrimination on the basis of sexual orientation and gender identity] (Law 3/2016). Madrid: Government of Madrid.

Government of Murcia. (2016). Ley de igualdad social de lesbianas, gays, bisexuales, transexuales, transgénero e intersexuales y de políticas públicas contra la discriminación por orientación sexual e identidad de género [Regional law on social equality for lesbian, gay, bisexual, transsexual, transgender and intersex people, and on public policies of non-discrimination on the basis of sexual orientation and gender identity] (Law 8/2016). Murcia: Government of Murcia.

Government of Navarra. (2017). Ley para la igualdad social de las personas LGTBI+ [Regional law on social equality for LGTBI+ people] (Law 8/2017). Navarra: Government of Navarra.

Government of the Balearic Islands. (2016). Ley para garantizar los derechos de lesbianas, gays, trans, bisexuales e intersexuales y para erradicar la LGTBI fobia [Regional law to guarantee the rights of lesbian, gay, trans, bisexual and intersex people, and to erradicate LGTBI-phobia] (Law 8/2016). Balearic Islands: Government of the Balearic Islands.

Government of the Basque Country. (2012). Ley de derechos de las personas transexuales [Regional law on the rights of transsexual people] (Law 14/2012). Basque Country: Government of the Basque Country.

Government of the Basque Country. (2019). Ley de modificación de la ley 14/2012, de no discriminación por motivos de identidad de género y reconocimiento de los derechos de las personas transexuales [Regional law modifying the 14/2012 law on nondiscrimination on the basis of gender identity and the recognition of the rights of transsexual people] (Law 14/2019). Basque Country: Government of the Basque Country.

Government of the Canary Islands. (2014). Ley de no discriminación por motivos de identidad de género y de reconocimiento de los derechos de las personas transexuales [Regional Law on non-discrimination on the 
basis of gender identity and the recognition of the rights of transsexual people] (Law 8/2014). Canary Islands: Government of the Canary Islands.

Government of Uruguay. (2018). Ley integral para personas trans [National and comprehensive law on trans people] (Law 104/019). Montevideo: Registro Nacional de Leyes.

Government of Valencia. (2017). Ley integral de reconocimiento del derecho a la identidad y la expresión de género [Regional and comprehensive law on the right of gender identity and expression] (Law 6/2017). Valencia: Government of Valencia.

Government of Valencia. (2019). Ley de igualdad de las personas $L G T B I$ [Regional law on the equality of LGTBI people] (Law 23/2018). Valencia: Government of Valencia.

Hemmings, C. (2012). Sexuality, subjectivity... and political economy? Subjectivity, 5(2), 121-139.

Krizsan, A., \& Lombardo, E. (2013). The quality of gender equality policies: A discursive approach. European Journal of Women's Studies, 20(1), 77-92.

Lombardo, E., Meier, P., \& Verloo, M. (Eds.). (2009). The discursive politics of gender equality. Stretching, bending and policy-making. London: Routledge.

Merck, M. (2004). Sexuality, subjectivity and...economics? New Formations, 52, 82-93.

Missé, M. (2018). A la conquista del cuerpo equivocado [Conquering the wrong body]. Barcelona: Egalés.

Muñoz, J. E. (2009). Cruising utopia: The then and there of queer futurity. New York, NY: NYU Press.
Platero, R. L. (2011). The narratives of transgender rights mobilization in Spain. Sexualities, 14(5), 597-614.

Platero, R. L. (2014). The influence of psychiatric and legal discourses on parents of gender-nonconforming children and trans youths in Spain. Journal of GLBT Family Studies, 10(1/2), 145-167.

Platero, R. L., \& Ortega, E. (2016). Building coalitions: The interconnections between feminism and trans* activism in Spain. Journal of Lesbian Studies, 20(1), 46-64.

Spade, D. (2011). Normal life: Administrative violence, critical trans politics and the limits of the law. Brooklyn, NY: South End Press.

Spanish Government. (2007). Ley reguladora de la rectificación registral de la mención relativa al sexo de las personas [Law regulating the rectification of the register, concerning peoples' sex] (Law 3/2007, 15 March). Madrid: Spanish Government.

Stryker, S. (1994). My words to Victor Frankenstein above the village of Chamounix: Performing transgender rage. GLQ, 1(3), 237-254.

Stryker, S. (2017). Transgender history: The roots of todays' revolution. Berkeley, CA: Seal Press.

Suess, A. (2018). Derechos de las personas trans e intersex: Revisión del marco legislativo en el contexto español desde una perspectiva de despatologización y derechos humanos [Trans and intersex rights: Reviewing Spanish legislation from a depathologization and human rights perspective]. Revista Derecho y Salud, 28, 97-115.

\section{About the Author}

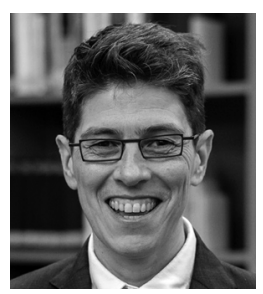

R. Lucas Platero is a Juan de la Cierva Researcher at the Social Psychology Department (Universitat Autònoma de Barcelona) and Director of publications for trans* studies at Bellaterra Publishing House. His academic journey is strongly linked to his activist life, gradually shifting his social activism to an activism based on academic research to which he has made multiple contributions. In 2020, Platero received the Emma Goldman Award, supporting innovative research and knowledge on feminist and inequality issues in Europe. 